\title{
An A utocrine Role for Pituitary GABA: Activation of GABA-B Receptors and Regulation of Growth Hormone Levels
}

\author{
Katia Gamel-Didelon ${ }^{a}$ Claudia Corsi c Giancarlo Pepeuc Heike J ung ${ }^{\text {b }}$ \\ Manfred Gratzla Artur Mayerhofera \\ aAnatomisches Institut der Universität München, München, and bLilly Germany, Bad Homburg, Deutschland; \\ 'Dipartimento di Farmacologia, Università di Firenze, Firenze, Italia
}

\section{Key Words}

$\gamma$-Aminobutyric acid $\cdot \gamma$-Aminobutyric acid receptors . Growth hormone. Somatotropes - GH3 cell line

\begin{abstract}
There is increasing evidence suggesting that the neurotransmitter $\gamma$-aminobutyric acid (GABA) is a local factor involved in the regulation of endocrine organs. Examples of such functions are documented in the pancreas, but recent results suggest that GABA may act in a similar way in the pituitary, in which GABA receptors are expressed and pituitary growth hormone $(\mathrm{GH})$ cells provide a source of GABA. We hypothesised that GABA secreted in somatotropes may act as an autoregulatory signaling molecule. To test this hypothesis we first examined the nature of GABA receptors expressed by $\mathrm{GH}$ cells. RT-PCR analysis demonstrated that GABA-B receptor subunits $R 1$ and R2 are present in the whole rat pituitary. Laser microdissection of immunostained GH cells, followed by RT-PCR as well as immunoelectron microscopy, showed that GABA-B receptors are expressed on somatotropes. To investigate GABA-B receptor function in somatotropes, we used rat $\mathrm{GH} 3$ adenoma cells, which, like pituitary $\mathrm{GH}$ cells, express GABA-B R1 and R2 (as assessed by RT-PCR and immunoelectron microscopy) and produce GABA (checked by high performance liquid chromatography). After inhibition of endogenous GABA synthesis, GH production was stimulated by baclofen, a chromatography).
\end{abstract}

After inhibition of endogenous GABA synthesis, GH production was stimulated by baclofen, a GABA-B receptor agonist. By contrast, blocking GABA-B receptors by an antagonist, phaclofen, decreased GH levels. We conclude that in $\mathrm{GH}$-producing cells, GABA acts as an autocrine factor via GABA-B receptors to control GH levels.

Copyright $\odot 2002$ S. Karger AG, Basel

\section{Introduction}

Production and secretion of hormones in the pituitary is controlled by several hypothalamic factors. Besides the classic releasing and inhibitory factors synthesised by the hypothalamus, the neurotransmitter $\gamma$-aminobutyric acid (GABA) regulates the production of pituitary hormones, including corticotropin (ACTH), growth hormone $(\mathrm{GH})$, thyreostimulating hormone (TSH), luteinizing hormone (LH) and prolactin (PRL). The effects of GABA depend on several factors, such as concentration, developmental stage and experimental conditions, and may be mediated either directly or indirectly [1-7]. In the hypothalamus, for instance, GABA acts on neurons secreting releasing factors [8, 9]. In addition, axons of GABAergic hypothalamic neurons terminate on endocrine pro-opiomelanocortin (POMC) cells of the intermediate lobe of the pituitary [10, 11]. Moreover, GABAergic neurons extend to the median eminence, where GABA is secreted into portal vessels and reaches the anterior pituitary.

\section{KARGER \\ Fax +4161306 1234 \\ E-Mail karger@karger.ch \\ www. karger.com

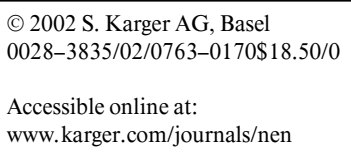

\footnotetext{
Artur Mayerhofer

Anatomisches Institut der Universität München

Biedersteiner Strasse 29

D-80802 München (Germany)

Tel. +49 894140 3150, Fax +49 89397 035, E-Mail Mayerhofer@lrz.uni-muenchen.de
} 
Recently, additional sites of GABA production have been identified in GH cells of the anterior pituitary and POMC cells of the intermediate lobe in rat and monkey pituitaries [12]. The same report showed that GH cells are immunoreactive for a GABA-A receptor subunit $(\gamma 2)$. These findings, together with the fact that all classes of GABA receptors $(\mathrm{A}, \mathrm{B}, \mathrm{C})$ were found to be present in the anterior lobe [12-18], imply that GABA may exert autocrine actions within the adenohypophysis. This action appears to include regulation of $\mathrm{GH}$, as seen, for example, in rats $[3,7,16]$. However, neither the mechanisms of action of endogenous GABA nor its consequences for $\mathrm{GH}$ cell function are currently known.

In order to define the role of GABA secreted by somatotropes, we used a rat pituitary adenoma cell line, GH3 [19]. $\mathrm{GH} 3$ cells, like GH cells, are able to produce and store GABA [12]. Therefore they represent a valuable model for studying the role of GABA in GH-producing cells. The present work demonstrates that $\mathrm{GH} 3$ cells express functional GABA-B receptors involved in the regulation of $\mathrm{GH}$ synthesis and secretion. A similar mechanism of regulation of GH synthesis may occur in pituitary GH cells, since we show that they also bear GABA-B receptors.

\section{Methods}

\section{Animals}

Pituitary glands were obtained from male and female SpragueDawley rats that had been bred at the Technische Universität München. According to our animal care guidelines, they were painlessly killed under ether anaesthesia and their pituitaries, and in some cases brains, were removed and either processed for paraffinembedding or electron microscopy, or they were frozen for RNA extraction, as described previously [12].

\section{Culture Procedures of Rat GH3 Cells}

The general culture procedures applied to $\mathrm{GH} 3$ cells have been described previously [20]. GH3 cells were grown in F12-DME (Sigma, Deisenhofen, Germany) containing 10\% fetal calf serum (FCS; PAA Laboratories, Linz, Austria) in 60-mm diameter Petri dishes purchased from Life Technologies (Rockville, Md., USA). They were submitted to treatments with $10^{-4}$ or $10^{-5} M$ GABA receptors agonists or antagonists (Tocris, Ballwin, Mo., USA) before reaching confluency. Unless otherwise stated, the treatments using two different concentrations of chemicals gave similar results and thus were pooled. These results were confirmed by a different handling procedure that included a 24-hour starvation step (without FCS) for synchronising the cells, followed by an additional day of culture in F12DME $+2.5 \%$ FCS. The chemicals were subsequently added to the $2.5 \%$ FCS-containing medium for the time of treatment. In some experiments, blocking glutamic acid decarboxylase (GAD) was necessary to prevent endogenous GABA synthesis by GH3 cells. To this end, we used $100 \mu M$ of $\gamma$-acetylenic GABA (Sigma) [21].
Laser Microdissection of Rat Pituitary GH Cells

PALM ${ }^{\circledR}$ Robot-MicroBeam Technology (P.A.L.M. GmbH, Bernried, Germany) was used for 'non-contact' laser microdissection of $\mathrm{GH}-\mathrm{imm}$ unostained cells from rat pituitaries. The samples were prepared following the guidelines of the manufacturer. Bouin-fixed, paraffin-embedded sections were deparaffinised and immunostained with an anti-GH antiserum (diluted 1:500; courtesy of Dr. Parlow, NHPP, Torrance, Calif., USA) following immunohistochemical methods previously described [12, 22, 23]. From these sections, samples were catapulted directly into the cap of a microfuge tube and stored at $-80^{\circ} \mathrm{C}$ in the RNAlater buffer (Qiagen, Hilden, Germany) until RNA isolation, reverse transcription (RT) and PCR were performed.

\section{$R N A$ Isolation and $R T-P C R$}

RNA isolation from either GH3 cells or rat tissues were performed using the RNeasy kit and the QIAshredder columns from Qiagen. The method used for RT (using MMLV, Stratagene, La Jolla, Calif., USA) and 18-mer polydeoxythymidine primers has been described previously [24-26]. PCR consisted of a 5-min hot start step followed by 40 cycles: $94^{\circ} \mathrm{C}$ for $30 \mathrm{~s}, 55^{\circ} \mathrm{C}$ for $1 \mathrm{~min}, 72^{\circ} \mathrm{C}$ for 30 $60 \mathrm{~s}$; final extension for $10 \mathrm{~min}$ at $72^{\circ} \mathrm{C}$.

From laser microdissected samples, RNA was prepared using the Purescript kit (Gentra Systems, Minneapolis, Minn., USA) and was subsequently treated with DNase, precipitated and resuspended in RNase-free water. This isolated RNA was reverse-transcribed using Superscript II (Life Technologies) and random hexamers (MWG Biotech, Ebersberg, Germany) according to the manufacturer's instructions. For cDNA amplification, a nested PCR strategy was employed. A first PCR step (PCR1) was performed, the PCR1 product was subsequently purified (MiniElute Kit, Qiagen) and used as template for a second PCR. For all experiments, the nature of the amplified cDNAs was confirmed by direct sequencing using one of the oligonucleotide primers (Agowa, Berlin, Germany).

Oligonucleotide primers were chosen to encompass exon-intron boundaries to avoid possible genomic DNA contamination. Primers designed for the R1 subunit do not distinguish between the splice variants R1a and R1b. They were purchased from MWG Biotech and their sequences are listed in table 1a, b. In addition a sense primer (5'-GTA CGT CTG GTT CCT CAT-3') was used in combination with nested RI-3' for the analysis of GH3 and pituitary samples (see fig. 2).

\section{Electron Microscopy}

GH3 cells and rat pituitaries were fixed on ice for $1 \mathrm{~h}$ with $2 \%$ paraformaldehyde and $0.5 \%$ glutaraldehyde in $10 \mathrm{~m} M$ PBS, pH 7.4. They were dehydrated with ethanol $\left(30 \%\right.$ at $0{ }^{\circ} \mathrm{C}, 50 \%$ at $-10{ }^{\circ} \mathrm{C}$, $70 \%$ at $-30^{\circ} \mathrm{C}$ ) and infiltrated at $-30^{\circ} \mathrm{C}$ with the hydrophilic resin Lowicryl K4M (Plano, Wetzlar, Germany). Polymerisation was achieved by exposure to ultraviolet light for 2 days at $-30^{\circ} \mathrm{C}$ and for 3 days at room temperature, using an EM AFS apparatus from Leica (Vienna, Austria). Following ultra thin sectioning, immunocytochemistry was performed as described previously [27]. For immunolocalisation of GABA-B R2, the primary antiserum was raised in rabbits and diluted 1:1,000 (courtesy of Graham Disney and Fiona Marshall, GlaxoWellcome Research and Development, Stevenage, UK). A secondary goat anti-rabbit antiserum was labelled either with 10-nm (immunostaining on GH3 cells) or 6-nm (double immunostaining on rat pituitaries) gold particles (diluted 1:20; Aurion, Wageningen, The Netherlands). For immunodetection of $\mathrm{GH}$, the first 
Table 1. Oligonucleotides used for RT-PCR

a Rat GABA-B R1a+b (Genbank accession No. Y10369 and Y10370) and positions of primers

\begin{tabular}{lll}
\hline R1-5' & 5' CTGGCCTATGATGCTATC 3' & 1402-1419 (R1a)/1054-1071 (R1b) \\
R1-3' & 5' CGGAATGTCTTGATGACC 3' & 1751-1734 (R1a)/1403-1386 (R1b) \\
Nested R1-5' & 5' AACTACAACAACCAGACC 3' & 1492-1509 (R1a)/1144-1161 (R1b) \\
Nested R1-3' & 5' AGATCATCCTTGGTGCTG 3' & 1676-1659 (R1a)/1328-1311 (R1b) \\
\hline b Rat GABA-B R2 (accession No. AF058795) and positions of primers & \\
\hline R2-5' & 5' CATCATCTTCTGCAGCAC 3' & $2328-2345$ \\
R2-3' & 5' TCTGTGAAGTTGCCCAAG 3' & $2681-2664$ \\
Nested R2-5' & 5' TCCAGTTCACACAGAACC 3' & $2426-2443$ \\
Nested R2-3' & 5' CCAGCTCTGTGATCTTCA 3' & $2563-2546$ \\
\hline
\end{tabular}

antibody was raised in monkeys (diluted 1:500; courtesy of Dr. Parlow, Torrance, Calif., USA) and the second antibody was a $10 \mathrm{~nm}$ gold-labelled anti-human antibody (diluted 1:20; Aurion). Sections were examined with the Zeiss electron microscope EM10.

\section{Western Blotting}

Western blotting was performed as described previously [28, 29]. In order to control small loading differences, Ponceau stainings of separated proteins were performed. In addition, for some experiments, $\beta$-actin was detected and used as an additional reference protein. To this end, images were digitalised and optical densities of Western blot results were evaluated using NIH Image, as described previously [25].

For detection of $\mathrm{GH}$, a monkey anti-GH primary antiserum (diluted 1:500) and peroxidase-conjugated goat anti-human immunoglobulins were used (diluted 1:5,000; Jacksons Immunoresearch Laboratories, West Grove, Pa., USA). Immunodetection of $\beta$-actin was achieved using a mouse anti- $\beta$ actin antibody purchased from Sigma (diluted 1:5,000) and peroxidase-conjugated goat anti-mouse immunoglobulins (diluted 1:5,000; Jacksons Immunoresearch Laboratories). Results were visualised using an enhanced chemiluminescence kit (ECL; Amersham Pharmacia Biotech, Little Chalfont, UK).

\section{Enzyme Immunoassay}

After treatment, the supernatants from confluent GH3 cells (4$10 \times 10^{6}$ cells) were harvested and stored at $-20^{\circ} \mathrm{C}$ until use. In order to measure the quantity of GH secreted by GH3 cells, a commercial enzyme immunoassay (EIA) test was used (Biotrak system, Amersham). GH levels were determined after reading the optical density at $450 \mathrm{~nm}$ with a spectrophotometric plate reader (Dynex Technologies, Chantilly, Va., USA). The values were finally expressed as ng GH. The sensitivity of the commercial test used was $1.7 \mathrm{ng} / \mathrm{ml}$ of $\mathrm{GH}$.

\section{High Performance Liquid Chromatography}

As for the EIA, the supernatants from the $\mathrm{GH} 3$ cell cultures were harvested after $24 \mathrm{~h}$ of treatment and stored at $-20^{\circ} \mathrm{C}$ until use. The culture medium was used as a reference. GABA analysis was carried out by a high performance liquid chromatography (HPLC) method with fluorimetric detection [30]. Briefly, amino acids were derivatized with mercaptoethanol and o-phtalaldehyde (OPA). The OPA derivatives were then separated on a $5-\mu M$ reverse-phase Nucleosil C18 column $(250 \times 4 \mathrm{~mm}$; Macherey-Nagel, Duren, Germany), kept at room temperature, using a mobile phase consisting of methanol and potassium acetate $(0.1 \mathrm{M}, \mathrm{pH}$ adjusted to 5.52 with glacial acetic acid) at a flow rate of $1.0 \mathrm{ml} / \mathrm{min}$ in a three-linear step gradient (from 25 to $90 \%$ methanol). This method detects GABA quantities as low as $100 \mathrm{fmol}$ per volume injected. In the samples, GABA levels were given as pmol/ $10^{6}$ cells.

\section{Statistical Analyses}

For statistical data analyses, ANOVA and the Student-NewmanKeuls multiple comparison test (Western blot results), or the Student paired $t$ test (HPLC and EIA data) were employed.

\section{Results}

\section{GABA-B Receptor Subunits Are Expressed in GH-Producing Cells of the Rat Pituitary and in GH3 Cells}

Immunoelectron microscopy experiments, using double immunostaining, identified GH-immunoreactive cells to possess GABA-B R2 subunits at their membrane (fig. 1a). The expression of R2 by GH cells was confirmed at the mRNA level. To this end, rat pituitary sections immunostained for $\mathrm{GH}$ were submitted to laser microdissection. RNA was extracted, RT-PCR experiments performed and, using a nested PCR approach, the GABA-B $\mathrm{R} 2$ subunit was detected in GH-immunoreactive cells. GABA-B R2 was absent in samples in which GH-immunoreactive cells had been destroyed by a laser beam (fig. 1b).

Both R1 and R2 subunits of the GABA-B receptor are also expressed in cultured GH3 cells, as shown by RT- 


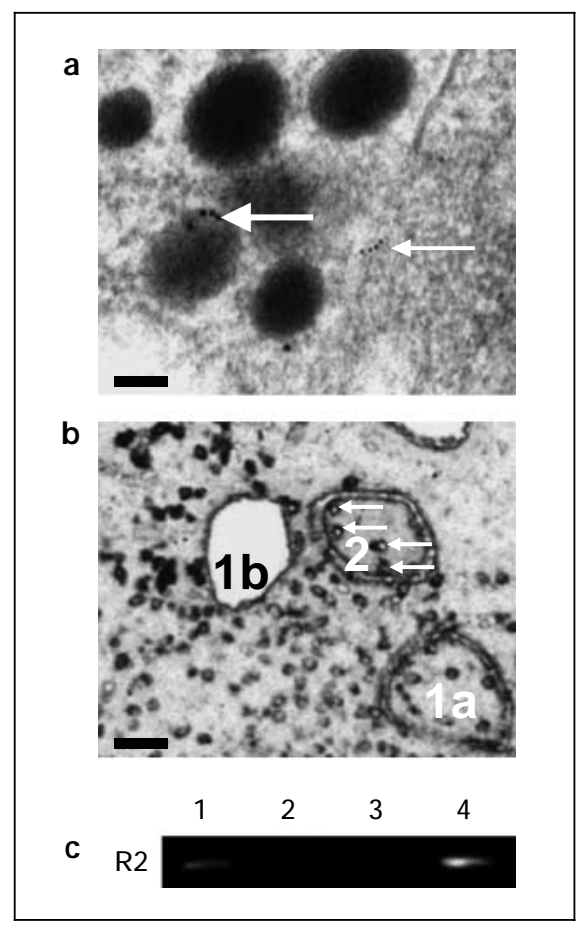

Fig. 1. GH cells express GABA-B R2 subunit. a Immunoelectron microscopy performed on an ultra thin section of a rat pituitary. The nature of the cell shown was clearly identified by immunostaining of GH-containing secretory granules (10-nm gold; bold arrow). At the membrane of the GH cell, 6-nm gold labels indicate the presence of GABA-B R2 subunit proteins (narrow arrow). Bar equivalent to $100 \mathrm{~nm}$. b Section of a rat pituitary in which GH cells were identified by immunohistochemistry and submitted to laser microdissection (upper panel). Groups of GH-positive cells were separated from the surrounding tissue by a laser beam (1a) and subsequently catapulted (1b) inside the cap of a microfuge tube. To control false positives, all $\mathrm{GH}$ cells (arrows) were destroyed in another area by laser shots before laser excision (2). Bar equivalent to $80 \mu \mathrm{m}$. c RNA extracted from laser-dissected pituitary GH cells was subsequently reverse transcribed and submitted to nested PCR amplification. GH-producing cells express GABA-B R2 (lane 1). No GABA-B R2 product is detected after destroying $\mathrm{GH}$ cells in the surrounding tissue (lane 2). Lane 3 is a control (PCR reaction without template). Lane 4 shows the expression of $\mathrm{R} 2$ in the whole brain of a 4-week-old rat (positive control). Sequencing of RT-PCR products confirmed their identity.

PCR and sequencing (fig. 2a). Furthermore, immunoelectron microscopy showed localisation of the $\mathrm{R} 2$ subunit at GH3 cell membranes (fig. 2b).

\section{GABA Is Produced in GH3 Cells}

Since GH3 cells have previously been shown to express functional glutamic acid decarboxylase (GAD) and the vesicular inhibitory amino acid transporter/vesicular $\gamma$-aminobutyric acid transporter (VIAAT/VGAT) [12], a

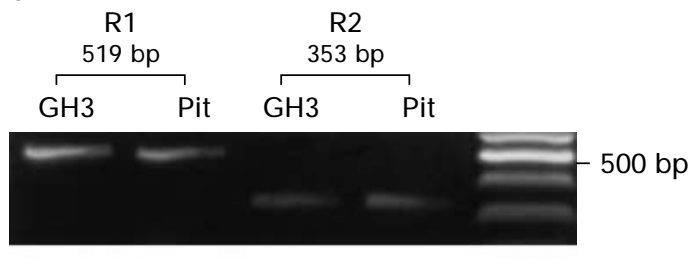

b

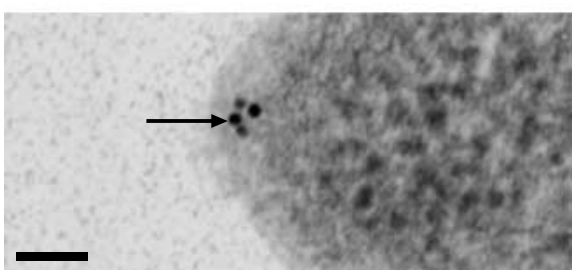

Fig. 2. GABA-B receptor subunits in GH3 cells. a RNA samples extracted from $\mathrm{GH} 3$ cells and rat pituitary were reverse transcribed and used for PCRs using specific primers for GABA-B receptors R1 and $\mathrm{R} 2$ subunits. Both subunits are expressed in GH3 cells and in whole rat pituitary (Pit). Control experiments without template were negative (not shown). Sequencing of RT-PCR products confirmed their identity. b Immunoelectron microscopy experiments localised the GABA-B R2 subunit protein at GH3 cell membrane (10-nm gold particles, arrow). Bar equivalent to $50 \mathrm{~nm}$.

HPLC measurements were now performed in order to quantify GABA secretion by GH3 cells. The amount of GABA released $( \pm$ SEM) after $24 \mathrm{~h}$ was $1.72 \pm 0.54$ $\mathrm{nmol} / 10^{6}$ cells ( 3 series of experiments, $\mathrm{n}=5$ ).

\section{GABA-B Receptors Are Involved in the Control of GH Production and Secretion by GH3 Cells}

In order to examine the function of the GABA-B receptors present in $\mathrm{GH} 3$ cells, the cultures were treated with the GABA-B receptor antagonist phaclofen (pilot experiments were run in order to identify efficient phaclofen concentrations and the appropriate duration of treatment). The cellular and extracellular GH levels in the samples treated with phaclofen ( 10 or $100 \mu M$ for $24 \mathrm{~h}$ ) were compared with the ones of untreated controls. Cellular GH levels were analysed by SDS-PAGE and immunoblotting. The accuracy of the protein loading for the SDSPAGE was controlled by Ponceau staining of the mem- 


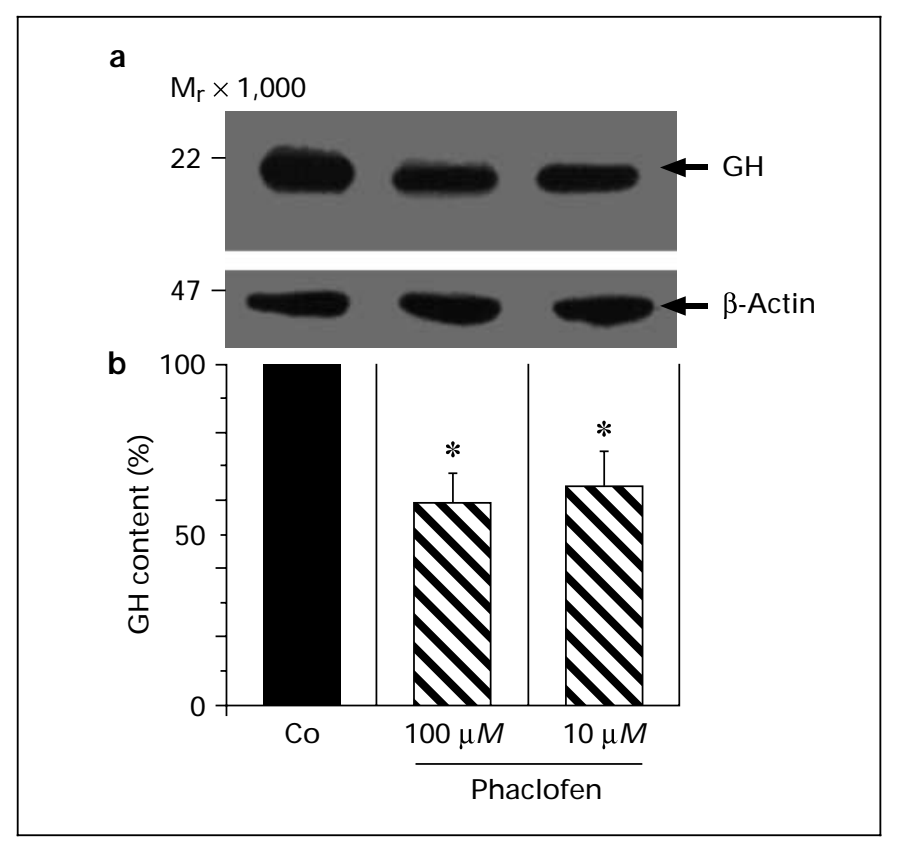

Fig. 3. Blockade of GABA-B receptors by phaclofen reduces GH production in $\mathrm{GH} 3$ cells. In order to block GABA-B receptors, GH3 cells were treated with phaclofen for $24 \mathrm{~h}$. After treatment, proteins were extracted and Western blots were performed to determine GH content. a A representative experiment is shown. The blockade of GABA-B receptors resulted in a decrease of the GH content by phaclofen used at 10 or $100 \mu M$ (upper panel); $\beta$-actin levels detected in the same experiment were unchanged (lower panel), indicating equal loading of the gel. b A graphical representation of 3 independent experiments is depicted and shows a decrease in the GH content of about $40 \%$. Results are expressed as percent of untreated controls (Co). Values are means + SEM. Differences between untreated and treated samples were evaluated using ANOVA and Student-Newman-Keuls tests; $* \mathrm{p}<0.05$.

branes. Blocking of GABA-B receptors resulted in decreased GH content compared with untreated control cells $(n=8)$. In some cases, $G H$ values were normalised to levels of a reference protein, $\beta$-actin $(n=3)$. The values obtained after optical density analysis of GH levels revealed statistically significant decreases of about $40 \%$ (fig. 3).

GH secretion was also modified by phaclofen treatment, as shown by the results of the GH EIA. Supernatants of untreated cells of two different series of experiments contained $27.39 \pm 3.01 \mathrm{ng} \mathrm{GH}( \pm \mathrm{SEM})$. Following the blockade of GABA-B receptors by phaclofen, $\mathrm{GH}$ levels were reduced by $60 \%(10.58 \pm 0.75 \mathrm{ng} \mathrm{GH} ; \mathrm{p}=$ $0.0023)$. a

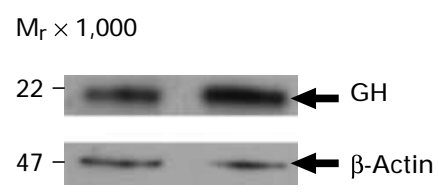

b

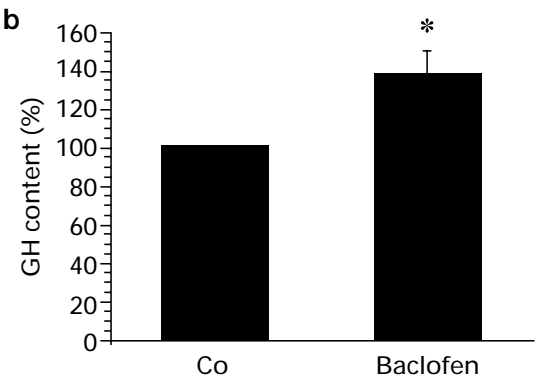

Fig. 4. Activation of GABA-B receptors by baclofen stimulates $\mathrm{GH}$ production in GH3 cells. An inhibitor of GABA synthesis ( $100 \mu \mathrm{M}$ of $\gamma$-acetylenic GABA) was added to the cell culture medium $2 \mathrm{~h}$ before the supplement of baclofen $(24 \mathrm{~h})$. After treatment, proteins were extracted and Western blots performed to analyse GH production. Four independent experiments were performed. a As shown in the upper panel, use of baclofen increased $\mathrm{GH}$ production. This was observed in 3 of 4 experiments (no change was detected in 1 experiment). $\beta$-Actin levels were unchanged (lower panel), indicating equal loading of the gel. b Activating GABA-B receptors led to a $29-47 \%$ increase of GH content. A graphical representation of 3 experiments showing similar results is given. GH contents are expressed as percent of untreated control samples (Co). Values are means + SEM. Differences between untreated and treated samples were evaluated using ANOVA and Student-Newman-Keuls tests; * $\mathrm{p}<0.05$.

The samples used for the EIA and one additional series of samples were also analysed by HPLC in order to determine GABA levels. The average amount of GABA released $( \pm$ SEM) by untreated GH3 cells was $1.72 \pm$ $0.54 \mathrm{nmol} / 10^{6}$ cells $/ 24 \mathrm{~h}(\mathrm{n}=5)$. Like for $\mathrm{GH}$, we observed that GABA levels in the medium were decreased by $20-80 \%$ in all samples treated with phaclofen $(0.87 \pm$ $0.56 \mathrm{nmol}$ GABA; $p=0.0022$ ).

In 3 different experiments, consisting each of 2 control samples and 2 samples treated with $100 \mu M$ of the GABA$B$ receptor agonist baclofen, the cellular levels of $\mathrm{GH}$ were analysed by SDS-PAGE and immunoblotting. The analysis showed that direct activation of GABA-B receptors increased GH levels. The accuracy of the protein loading for the SDS-PAGE was controlled by Ponceau staining of 
the membranes and, in some cases, by immunoblotting for a reference protein, $\beta$-actin. The values obtained after optical density analysis of $\mathrm{GH}$ levels were expressed as percent of untreated control samples and showed statistically significant increases of $\mathrm{GH}$ levels, ranging from 29 to $47 \%$ (fig. 4). In order to avoid interference of endogenous GABA produced by GH3 cells, a blocker of GABA synthesis $(100 \mu M$ of $\gamma$-acetylenic GABA) was added to the culture medium $2 \mathrm{~h}$ before addition of baclofen for $24 \mathrm{~h}$.

\section{Discussion}

The results of our study show that $\mathrm{GH} / \mathrm{GH} 3$ cells produce GABA and express GABA-B receptors. We describe that GABA, via GABA-B receptors, is involved in the autocrine control of the $\mathrm{GH}$ cell phenotype.

GABA plays a role in the physiological regulation of pituitary functions [1-7]. It is well established that GABA is one of several signaling molecules involved in the control of $\mathrm{GH}$ production [3, 7, 31, 32]. GABA-affecting hormone secretion by pituitary endocrine cells is produced in the hypothalamus [8-11], but, as shown recently, also within the pituitary itself, namely in POMC and in $\mathrm{GH}$ cells [12]. GH3 cells are somatotropic cells derived from a rat $\mathrm{GH}$ pituitary adenoma. They provide a well established, widely used model for the study of the regulation of GH and PRL production [19, 33]. Since our previous results showed that $\mathrm{GH} 3$ cells produce GABA, we used this cell line to investigate whether GABA derived from $\mathrm{GH}$-producing cells may contribute to the regulation of $\mathrm{GH}$ synthesis and release. This mechanism of regulation may involve all three different types of GABA receptors, since evidence of their existence in the pituitary has been provided [12-18, 34].

In the current study, we focussed on GABA-B receptors. Their presence was recently confirmed at the molecular level in the anterior lobe of rat pituitaries and in cells derived from the mouse intermediate lobe [35, 36]. Results of the present study show that GABA-B receptors are also expressed in a particular cell type of the anterior lobe of the pituitary, the GH cell. Using laser microdissection [37-39] of rat pituitary GH cells followed by RT-PCR, we found that $\mathrm{GH}$ cells possess mRNA for GABA-B receptors. This result was confirmed by immunoelectron microscopy.

Likewise, GH3 adenoma cells express GABA-B receptor subunits, as shown in the present study, and were therefore used to examine GABA-B receptor-mediated events. To this end we blocked the action of GABA by treating GH3 cells with the GABA-B antagonist phaclofen. Phaclofen treatment led to a decreased GH content. A reduction in $\mathrm{GH}$ levels in the medium, and thus presumably in GH release, was also measured. Results were obtained using concentrations determined in pilot studies. We chose not to study dose-response relations, since they appear questionable in a system in which GABA is produced endogenously. Taken together, our results imply that levels of GH inside the cells and in the medium were decreasing in parallel. We therefore hypothesise that a role for GABA may be to maintain or increase $\mathrm{GH}$ production via GABA-B receptors.

To examine this possibility further, endogenous GABA synthesis was blocked by preventing the decarboxylation of $L$-glutamate, using $\gamma$-acetylenic GABA [21], before activation of GABA-B receptors by a GABA-B receptor agonist, baclofen. Indeed, baclofen increased $\mathrm{GH}$ content after $24 \mathrm{~h}$ of treatment, supporting our conclusion that GABA regulates $\mathrm{GH}$ via GABA-B receptors.

These results obtained in a cell culture system are in line with in vivo results showing an increase in GH secretion following baclofen administration in humans [40, 41], or following GABA treatment in newborn rats [3, 31]. Therefore our results from $\mathrm{GH} 3$ cell and the localisation of GABA-B receptors at the membrane of pituitary $\mathrm{GH}$ cells are probably of relevance to mammalian species, including humans, and highlight a novel aspect of $\mathrm{GH}$ cell regulation.

Previously, we reported that VIAAT and GAD are colocalised to secretory granules of GH cells [12], a result suggesting corelease. Indeed, in the present study we provide evidence for cosecretion of $\mathrm{GH}$ and GABA, using GH3 cells. Provided that pituitary GABA is released together with $\mathrm{GH}$, this may imply that GABA exerts an autocrine positive feedback on $\mathrm{GH}$ cells. By acting on GABA-B receptors, it may thus stimulate both $\mathrm{GH}$ production as well as its own secretion.

GABA is mainly known for its synaptic role as a major inhibitory neurotransmitter of the central nervous system. That it can be produced and act in other, nonneuronal tissues is an emerging field. A role for GABA in endocrine tissues has been shown for the pancreas. There GABA is cosecreted with insulin from $\beta$-cells and involved in the inhibitory action of glucose on glucagon release by activating GABA-A receptors present in $\alpha$-cells [42]. Our work in the pituitary and GH3 cells provides a new example for an endocrine role of GABA acting as a stimulatory autocrine regulator of $\mathrm{GH}$ production.

Neuroendocrinology 2002;76:170-177 


\section{Acknowledgments}

We are grateful to Gabriele Terfloth for her excellent help in performing electron microscopical studies. We also thank Marlies Rauchfuss, Barbara Zschiesche, Andrea Thalhammer, Romi Rämsch and Andreas Mauermayer for their technical assistance, and Christof Geigerseder for helpful discussions. The laser microdissec- tion device was made available through collaboration with Dr. Viktor Meineke, Munich. The collaboration between the Universities of Munich and Florence arose thanks to Prof. Andrea Nistri and Dr. Maria-Grazia Giovannini. This work was supported by the Eli Lilly International Foundation; the Volkswagen Stiftung, and a grant from the University of Florence.

\section{References}

1 Makara GB, Stark E: Effects of $\gamma$-aminobutyric acid (GABA) and GABA antagonist drugs on ACTH release. Neuroendocrinology 1974;16: 178-190.

2 Tomiko SA, Taraskevich PS, Douglas WW: GABA acts directly on cells of pituitary pars intermedia to alter hormone output. Nature 1983;301:706-707.

3 Acs Z, Szabo B, Kapocs G, Makara GB: $\gamma$-Aminobutyric acid stimulates pituitary growth hormone secretion in the neonatal rat. A superfusion study. Endocrinology 1987;120:1790_ 1798.

4 Tapia-Arancibia L, Roussel JP, Astier H: Evidence for a dual effect of $\gamma$-aminobutyric acid on thyrotropin (TSH)-releasing hormone-induced TSH release from perifused rat pituitaries. Endocrinology 1987;121:980-986.

5 Virmani MA, Stojilkovic SS, Catt KJ: Stimulation of luteinizing hormone release by $\gamma$-aminobutyric acid (GABA) agonists: Mediation by GABAA-type receptors and activation of chloride and voltage-sensitive calcium channels. Endocrinology 1990;126:2499-2505.

6 Lux-Lantos V, Rey E, Libertun C: Activation of GABA $B$ receptors in the anterior pituitary inhibits prolactin and luteinizing hormone secretion. Neuroendocrinology 1992;56:687693.

7 Anderson RA, Mitchell R: Effects of $\gamma$-aminobutyric acid receptor agonists on the secretion of growth hormone, luteinizing hormone, adrenocorticotrophic hormone and thyroid-stimulating hormone from the rat pituitary gland in vitro. J Endocrinol 1986;108:1-8.

8 Jung H, Shannon EM, Fritschy JM, Ojeda SR: Several GABAA receptor subunits are expressed in LHRH neurons of juvenile female rats. Brain Res 1998;780:218-229.

9 Keen KL, Burich AJ, Mitsushima D, Kasuya E, Terasawa E: Effects of pulsatile infusion of the GABA(A) receptor blocker bicuculline on the onset of puberty in female rhesus monkeys. Endocrinology 1999; 140:5257-5266.

10 Vincent SR, Hökfelt T, Wu JY: GABA neuron systems in hypothalamus and the pituitary gland. Immunohistochemical demonstration using antibodies against glutamate decarboxylase. Neuroendocrinology 1982;34:117-125.
11 Schimchowitsch S, Vuillez P, Tappaz ML, Klein MJ, Stoeckel ME: Systematic presence of GABA-immunoreactivity in the tubero-infundibular and tubero-hypophyseal dopaminergic axonal systems: An ultrastructural immunogold study on several mammals. Exp Brain Res 1991;83:575-586.

12 Mayerhofer A, Höhne-Zell B, Gamel-Didelon K, Jung H, Redecker P, Grube D, Urbanski HF, Gasnier B, Fritschy JM, Gratzl M: $\gamma$-Aminobutyric acid (GABA): A para- and/or autocrine hormone in the pituitary. FASEB J 2001; 15;1089-1091.

13 Berman JA, Roberts JL, Pritchett DB: Molecular and pharmacological characterization of GABAA receptors in the rat pituitary. J Neurochem 1994;63:1948-1954.

14 Boue-Grabot E, Dufy B, Garret M: Molecular diversity of GABA-gated chloride channels in the rat anterior pituitary. Brain Res 1995;704: 125-129.

15 Boue-Grabot E, Taupignon A, Tramu G, Garret M: Molecular and electrophysiological evidence for a GABAc receptor in thyrotropinsecreting cells. Endocrinology 2000;141:16271632-

16 Rey-Roldan EB, Lux-Lantos AR, GonzalezIglesias AE, Becu-Villalobos D, Libertun C: Baclofen, a $\gamma$-aminobutyric acid B agonist, modifies hormonal secretion in pituitary cells from infantile female rats. Life Sci 1996;58:10591065.

17 Rey-Roldan EB, Lux-Lantos V, Chamson-Reig A, Libertun C: In vivo interaction of baclofen, TRH and serotonin on PRL and TSH secretion in the developing and adult male and female rats. Life Sci 1997;62:2283-2290.

18 Lux-Lantos V, Becu-Villalobos D, Bianchi M, Rey-Roldan E, Chamson-Reig A, Pignataro O, Libertun C: GABA(B) receptors in anterior pituitary cells. Mechanism of action coupled to endocrine effects. Neuroendocrinology 2001; 73:334-343.

19 Tashjian AH Jr, Bancroft FC, Levine L: Production of both prolactin and growth hormone by clonal strains of rat pituitary tumor cells. Differential effects of hydrocortisone and tissue extracts. J Cell Biol 1970;47:61-70.

20 Lahr G, Mayerhofer A, Bucher S, Barthels D, Wille W, Gratzl M: Neural cell adhesion molecules in rat endocrine tissues and tumor cells: Distribution and molecular analysis. Endocrinology 1993;132:1207-1217.
21 Rosenstein RE, Chuluyan HE, Pereyra EN, Cardinali DP: Release and effect of $\gamma$-aminobutyric acid (GABA) on rat pineal melatonin production in vitro. Cell Mol Neurobiol 1989;9: 207-219.

22 Mayerhofer A, Dissen GA, Parrott JA, Hill DF, Mayerhofer D, Garfield RE, Costa ME, Skinner MK, Ojeda SR: Involvement of nerve growth factor in the ovulatory cascade: trkA receptor activation ihibits gap junctional communication between thecal cells. Endocrinology 1996;137:5662-5670.

23 Frungieri MB, Urbanski HF, Hohne-Zell B, Mayerhofer A: Neuronal elements in the testis of the rhesus monkey: Ontogeny, characterization and relationship to testicular cells. Neuroendocrinology 2000;71:43-50.

24 Mayerhofer A, Smith GD, Danilchik M, Levine JE, Wolf DP, Dissen GA, Ojeda SR: Oocytes are a source of catecholamines in the primate ovary: Evidence for a cell-cell regulatory loop. Proc Natl Acad Sci USA 1998;95: 10990-10995.

25 Mayerhofer A, Hemmings HC Jr, Snyder GL, Greengard P, Boddien S, Berg U, Brucker C: Functional dopamine-1 receptors and DARPP32 are expressed in human ovary and granulosa luteal cells in vitro. $\mathrm{J}$ Clin Endocrinol Metab 1999;84:257-264.

26 Bulling A, Berg FD, Berg U, Duffy DM, Stouffer RL, Ojeda SR, Gratzl M, Mayerhofer A: Identification of an ovarian voltage-activated $\mathrm{Na}^{+}$-channel type: Hints to involvement in luteolysis. Mol Endocrinol 2000;14:1064-1074.

27 Höhne-Zell B, Gratzl M: Adrenal chromaffin cells contain functionally different SNAP-25 monomers and SNAP-25/syntaxin heterodimers. FEBS Lett 1996;394:109-116.

28 Mayerhofer A, Russell LD, Grothe C, Rudolf M, Gratzl M: Presence and localization of a 30$\mathrm{kDa}$ basic fibroblast growth factor-like protein in rodent testes. Endocrinology 1991;129;921924.

29 Mayerhofer A, Lahr G, Gratzl M: Expression of the neural cell adhesion molecule in endocrine cells of the ovary. Endocrinology 1991; 129:792-800. 
30 Melani A, Pantoni L, Corsi C, Bianchi L, Monopoli A, Bertorelli R, Pepeu G, Pedata F: Striatal outflow of adenosine, excitatory amino acids, $\gamma$-aminobutyric acid, and taurine in awake freely moving rats after middle cerebral artery occlusion: Correlations with neurological deficit and histopathological damage. Stroke 1999,30:2448-2454.

31 Pinilla L, Gonzalez LC, Tena-Sempere M, Agular E: Cross-talk between excitatory and inhibitory amino acids in the regulation of growth hormone secretion in neonatal rats. Neuroendocrinology 2001;73:62-67.

32 Pinilla L, Gonzalez LC, Tena-Sempere M, Aguilar E: 5-HT1 and 5-HT2 receptor agonists blunt $+/-\alpha$-amino-3-hydroxy-5-methylisoxazole-4-propionic acid (AMPA)-stimulated GH secretion in prepubertal male rats. Eur J Endocrinol 2001;144:535-541.

33 McFerran DW, Stirland JA, Norris AJ, Khan RA, Takasuka N, Seymour ZC, Gill MS, Robertson WR, Loudon AS, Davis JR, White MR: Persistent synchronized oscillations in prolactin gene promoter activity in living pituitary cells. Endocrinology 2001;142:32553260
34 Louiset E, MCKernan R, Sieghart W, Vaudry $\mathrm{H}$ : Subunit composition and pharmacological characterization of $\gamma$-aminobutyric acid type A receptors in frog pituitary melanotrophs. Endocrinology 2000;141:1083-1092.

35 Bianchi M, Rey-Roldan E, Bettler B, Ristig D, Malitschek B, Libertun C, Lux-Lantos V: Ontogenic expression of anterior pituitary GABA(B) receptor subunits. Neuropharmacology 2001;40:185-192.

36 Chronwall BM, Davis TD, Severidt MW, Wolfe SE, McCarson KE, Beatty DM, Low MJ, Morris SJ, Enna SJ: Constitutive expression of functional GABA(B) receptors in mIL-tsA58 cells requires both $\operatorname{GABA}(\mathrm{B}(1))$ and $\mathrm{GA}$ BA(B(2)) genes. J Neurochem 2001;77:12371247.

37 Schutze K, Lahr G: Identification of expressed genes by laser-mediated manipulation of single cells. Nat Biotechnol 1998;16:737-742.

38 Frungieri MB, Calandra RS, Lustig L, Meineke V, Köhn FM, Vogt H-J, Mayerhofer A: Macrophages in the testes of infertile men: Number, distribution pattern and identification of expressed genes by laser microdissection and RTPCR analysis. Fertil Steril, in press.
39 Grosse J, Bulling A, Brucker C, Berg U, Amsterdam A, Mayerhofer A, Gratzl M: Synaptosome-associated protein of 25 kilodaltons in oocytes and steroid-producing cells of rat and human ovary: Molecular analysis and regulation by gonadotropins. Biol Reprod 2000;63: 643-650

40 Monteleone P, Maj M, Iovino M, Steardo L: Evidence for a sex difference in the basal growth hormone response to GABAergic stimulation in humans. Acta Endocrinol (Copenh.) 1988;119:353-357.

41 Orio F Jr, Palomba S, Colao A, Tenuta M, Dentico C, Petretta M, Lombardi G, Nappi C, Orio F: Growth hormone secretion after baclofen administration in different phases of the menstrual cycle in healthy women. Horm Res 2001;55:131-136.

42 Rorsman P, Berggren PO, Bokvist K, Ericson H, Mohler H, Ostenson CG, Smith PA: Glucose-inhibition of glucagon secretion involves activation of GABAA-receptor chloride channels. Nature 1989;341:233-236. 